\title{
PARTICIPATION AND MANAGEMENT IN PROTECTED NATURAL AREAS IN SPAIN: A PERSPECTIVE FROM SOCIAL CAPITAL AND TERRITORIAL DEVELOPMENT
}

\section{Carmen VÁZQUEZ VARELA • José María MARTÍNEZ NAVARRO}

University of Castilla-La Mancha

Faculty of Teaching Sciences and Humanities, Department of Geography and Town and Country Planning Av. de los Alfares, 44, 16071 Cuenca, Spain

carmen.vazquez@uclm.es•josemaria.martinez@uclm.es

\begin{abstract}
This contribution forms part of the framework of the CasoNatura research project in order to analyse the social trust in two protected natural areas of Castilla-La Mancha region (Spain). It aims to assess contexts of legitimacy for the Government and management of the space between the agents and institutions. Furthermore, it tries to detect the level of territorial identity which has the population with regard to their municipality, natural space and supra-local scales. Conflict detection of environmental, social and economic nature and how to manage them will be analysed and assessed through methodologies including both bibliographical and documentary sources and qualitative techniques of socio-territorial analysis: surveys of the local population and Governing Board of the Park, interviews with "qualified informants" and interviews with organisations/institutions located in the territory in question.
\end{abstract}

Key-words: social capital, natural protected areas, participation, management, normative trust, Spain, Serranía de Cuenca Natural Park, Cabañeros National Park.

\section{Introduction: a brief state of the art}

In the context of the rural deprived regions, the potential of exploring the relation between social capital and processes of development seems to be relevant, not necessarily because in the rural territories this relation is clearer or is translated in more efficient results for the development, but because the social capital acquires an unsuspected value due to the deficiency or non-existence of other factors of territorial competitiveness (economic capital, communication infrastructures, human capital...). In a global economy, most of the resources are highly mobile (economic capital, labour force, information), while deprived rural areas ${ }^{1}$ are at a disadvantage to compete successfully for these mobile

${ }^{1}$ Following the wise suggestion of one of the referees of this paper, it is worth to be critical about using "rural" as a direct synonym to "disadvantaged" or any other singular term. While this fact is often easily observed in peripheral and lagging rural regions, it is also very important to note that some types of rural areas, especially those closer to metropolitan areas or near the tourist developed coastal areas, are facing different developmental trends. 
resources (Bryden 1998). Therefore, the competitive advantage of these rural areas lies in resources that this author called "immobile": social capital, cultural capital, environmental capital, and local knowledge. Other scholars make reference to a similar distinction when they talk about development 'hard factors' and 'soft factors' (Copus and Spikerman 2003). Social capital in the context of rural territories and societies also takes on special importance because it introduces new nuances in the consideration of development, which happens to turn more humanistic and not purely economic. Quality of life is not generated only by the possession of quantifiable assets, but by the availability of other benefits that derive from social ties, trust relations, or the existence of a code of conduct accepted by the community.

Lee et al. (2005) analysed social capital in rural areas of six European countries within the framework of the research Project RESTRIM (Restructuring in Marginal Rural Areas) funded by the European Union. In this project, one of the aspects developed within the research has been the role of social capital and identity in relation to rural development and the relations between the two former. Among their findings the researchers underline the fact that not always can be assumed that publicly funded projects are precursors of "local engagement"; however, the key factor seems to be the strength of the existing local democracy. Where the social capital brings benefits, it is likely to be associated with a plurality of cultural identities, a mixing and interweaving of spatial scales (through, for example, diverse marketing strategies), and strong links with the multiple historical themes that characterise European rural areas (Árnason et al. 2009).

The social capital cannot be thought of as a property of closed and bounded rural communities which merely perpetuates the myths of rurality as a preserve of old traditions. In fact, some authors argue that while participation is seen as an indication of social inclusion and social engagement, it is not the case that non-participation equates with social exclusion (Shortall 2008). And yet, on the other hand, it is very much linked with ideas of place and identity.

The above mentioned RESTRIM project has already proved that social capital is in the roots of the process of creating and implementing a local collective action, as well as trust in the collective action is a distinctive character of social capital. Furthermore, community analysis revealed that trust in the collective action depends on the role played by the State in terms of responses to individual and collective needs. Briefly speaking, the analysis appears to show that the main function of the State, at the local level, is to provide public services. In other words, the lack of public services generates a community that does not rely on collective action; and, consequently, the will to build social capital weakens. The research findings emphasized that when a community is poor in social capital, the State must provide a higher standard of public services in order to create an atmosphere of confidence in the collective action. Only within this environment will the community invest in the construction of social capital; and it is only on the basis of high levels of social capital that the local community can plan and implement effective policies of rural development. Within this framework, the investment in social capital building becomes a priority of public action.

Nahapiet and Ghoshal (1998), Tsai and Ghoshal (1998) define social capital as "the sum of the actual and potential resources embedded within, and available through, and derived from the network of relationships possessed by an individual or social unit. Social capital thus comprises both the network and the assets that may be mobilized through 
that network." They divide it into the relational, cognitive and structural dimensions. The relational dimension is concerned with the behavioural embeddedness involving the nature of the relationships developed over time, including trust, norms and identity. Normative trust relates to the relational dimension of social capital because the norms create predictability and trustworthiness. Moreover, normative trust is manifest in the cognitive dimension of social capital that refers to shared representations, interpretations and systems of meaning, for example, to a shared vision among actors.

It is with specific reference to the park professionals as well as to the perception of the local population about the various environmental tools available to them that a research carried out in three national parks (Great Smoky Mountains National Park, USA, Virgin Islands National Park, U.S. Virgin Islands, and Podocarpus National Park, Ecuador) reveal that common assumptions about local residents as primarily motivated by rational economic stimuli are, at best, incomplete. Rather, the research reveals local distrust for park managers to be the most consistent predictor of active opposition toward neighbouring national parks, overshadowing traditional rational assessments of the benefits and disadvantages associated with the park presence among other factors. The research compares the relative explanatory power of different pathways leading toward park opposition and examines how perceptions of trustworthiness are developed (Stern 2008a).

On the other hand, as the existing studies suggest, one potential factor leading to a positive attitude towards the nature protected areas might be regional economic benefits or territorial expectations mainly through national/natural park-induced tourism (McCleave et al. 2006; Stern 2008a). These benefits are unlikely to be realized without successful tourism marketing and a clear protected area orientation of tourism businesses (Selby and Petäjistö 2009). Recent research suggests that the nature protected areas serve as considerable sources of regional income. At the same time, the economic benefits are regarded as a moderating tool when trying to reduce local resilience: "Local acceptance is maintained best through mechanisms that also support local economies" (Stoll-Kleemann and Job 2008).

\section{Nature protection from the perspective of social capital and territorial development}

Since the first establishment of the protected areas of outstanding natural beauty or species and habitat uniqueness, the dominant ideology underpinning their conservation has been that people are bad for natural resources (Gómez-Pompa and Kaus 1992). Policies and practice have, therefore, sought to exclude people and so discourage all forms of local participation. This style of conservation has neglected local people, their traditional knowledge and management systems, their institutions and social organisation, and the value of wild resources to them. The cost of conservation has been high. Social conflicts have grown in and around the protected areas, and conservation goals themselves have been threatened. Conservation itself needs rethinking. It has been dominated by the positivist and rationalist paradigm in which professionals assume they know best and so can analyse and influence natural resources in the ways they desire. Professionals tend to be reductionist in their approach, taking only the presence of a particular species or total species diversity as indicators of value. Such preservationist ideology is dominated by the desire to exclude local people. Yet, there is a growing empirical evidence to show that local people have long influenced natural systems in ways that improve biodiversity (Pimbert and Pretty 1995). Relationships of trust, reciprocity and exchange, common rules, 
norms and sanctions, and connectedness in groups are what make up social capital which is a necessary resource for shaping individual action to achieve positive biodiversity outcomes. New ideas spread more rapidly where there is a high social capital. There remain many practical and policy difficulties, however; not least regarding the need to invest in social capital formation and the many unresolved questions of how the state views the communities empowered to make their own decisions (Pretty and Smith 2004).

At this point, it should be remembered that the renewed focus on natural conservation points towards a more active approach, preserving the nature under the slogan "preserve is to develop", pursuing the overcoming of the problems directly affecting both the local population and the land owners (communal ownership, municipal property, private owners, etc.) as well as potential conflicts through the articulation of natural protected areas as tools for revitalizing local economies in marginalized rural areas (Martínez and Romero 2003) and becoming, by contrast, basic tools for social and economic development of the rural economies of the areas of influence of natural protected areas.

The problem with the positivist paradigm is that its absolutist position appears to exclude other possibilities. Yet the important point about positivism is that it is just one of many ways of describing the world, and what is needed is pluralistic ways of thinking about the world and acting to change it. Recent years have seen the emergence of a remarkable number of advances in a wide range of disciplines and fields of investigation. The sources include the so-called 'hard' sciences, such as physics, biology and mathematics, as well as the 'soft' sciences of economics, philosophy and sociology.

Five principles set out the crucial differences between these emerging paradigms and positivist science (Pretty 1994). The first is that any belief that sustainability can be precisely defined is wrong. The second is that problems are always open to interpretation. All actors have uniquely different perspectives on what is a problem and what constitutes improvement. In fact, Smith $(1990,1996)$ and Harvey $(1989)$ argue that space is produced through the social practices, science, planning, and technology, and space is lived in and understood through the symbols, language, and images. Subsequently the geographers have used these ideas to think about the production of natural spaces in preservation projects (Katz 1998). The third is that the resolution of one problem inevitably leads to the production of another 'problem-situation', as problems are endemic. The fourth is that the key feature now becomes the capacity of actors continually to learn about these changing conditions, so that they can act quickly to transform the existing activities. The fifth is that systems of learning and interaction are needed to seek the multiple perspectives of the various interested parties and encourage their greater involvement. Participation and collaboration are essential components of any system of inquiry, as any change cannot be effected without the full involvement of all stakeholders and the adequate representation of their views and perspectives.

This supports the view of those working in this area when they say that the proliferation of such protection (protected areas) as well as its priority location in rural mountain areas strongly characterised by deprivation, inexorably raises the issue of coordinating tools for town and country planning, environmental planning and rural development. To date, this socio-economic role, sometimes poorly understood, has resulted in the majority of cases in a management response in the form of public financing through economic and social development programmes for populations inside or around the natural protected areas, becoming a "collective compensation" or a "positive compensation" and 
trying with these plans to reduce the constraints imposed by the newly protected area (Garayo 2001).

However, not only the financial and management problems are the cause of possible failures associated with the natural spaces as development tools, but that responsibility is considerably extended, and other scholars (Mulero 2002) note the management and administration complexity arising from the extensive catalogue of the categories of protected areas at various scales (International, European, national, regional, etc.) that in many cases fuel the conceptual confusion between them (Florido and Lozano 2005). Moreover, the legal support in favour of the relationship "natural protected space/socio-economic development" is limited. Therefore, participation of the rural communities during the process of declaration (public reporting period) and in emerging conflicts subsequently rooted in it is not only thought useful but indispensable with a view to creating the awareness of the benefits generated by the protection which prevents the natural space itself to be perceived as a reflection of a lack of social solidarity model. This active participation is reflected in the slogan "to preserve with local people" that translates directly into overcoming obsolete consultation models giving way to shared responsibilities between stakeholders so that mutual support is consolidated in the programming, design and implementation of actions, plans, tools, etc., all of them with the common denominator of integration of the inhabitants in the global territorial policies to cover natural conservation and the rational and sustainable use of the territory.

\section{Study Area}

Based on this theoretical framework, and with the aspiration to achieve the objectives that we will detail further, we have selected eight case studies throughout the Spanish territory, two of them in Castilla-La Mancha region, both presented here to try to verify the hypothesis advanced in this stage of work (Fig. 1). The current Cabañeros National Park was declared Natural Park in 1988, but protection of this natural area was even more reinforced when a few years later, in 1995, it managed to obtain the highest level of national protection: National Park. With a total surface of 40,855.98 ha since 2005, the territory of Cabañeros transformed as a result of human activity throughout history, has become a peculiar landscape of extensive alluvial plains previously used for growing rain fed cereals and as rich seasonal pastures, a meadow landscape popularly known as Dehesa. The Park lies sheltered by the Chorito and Rocigalgo mountain ranges, among other mountains, completely covered with Mediterranean forest and scrub and perfectly preserved. There are municipalities included within the Area of Socio-Economic Influence of the National Park - four of them located in the province of Ciudad Real and two in the Toledo - one with a total population of 5,652 inhabitants in 2013 (Table 1). Today, cattle-breeding remains the common activity in the Park surroundings, with a production of cheese of excellent quality. In addition, cereal and olive tree continue to be cultivated.

The Serranía de Cuenca Natural Park, declared under regional law, was passed by law $5 / 2007$, with a surface of 73,726 has. The eleven municipalities concerned by the Serranía de Cuenca Natural Park embraced a population of 1,744 inhabitants the year 2013, unevenly spread throughout the territory, although the essential feature is the small size of their human settlements, with the exception of the provincial capital $(56,107$ inhabitants in 2013) (Table 2). Most of the working population is engaged in the primary sec- 
tor: forestry, livestock and agriculture account for the highest percentage. The industry is a weaker sector in the region. $70 \%$ of the surface is covered by public woodlands, mostly belonging to the municipality.

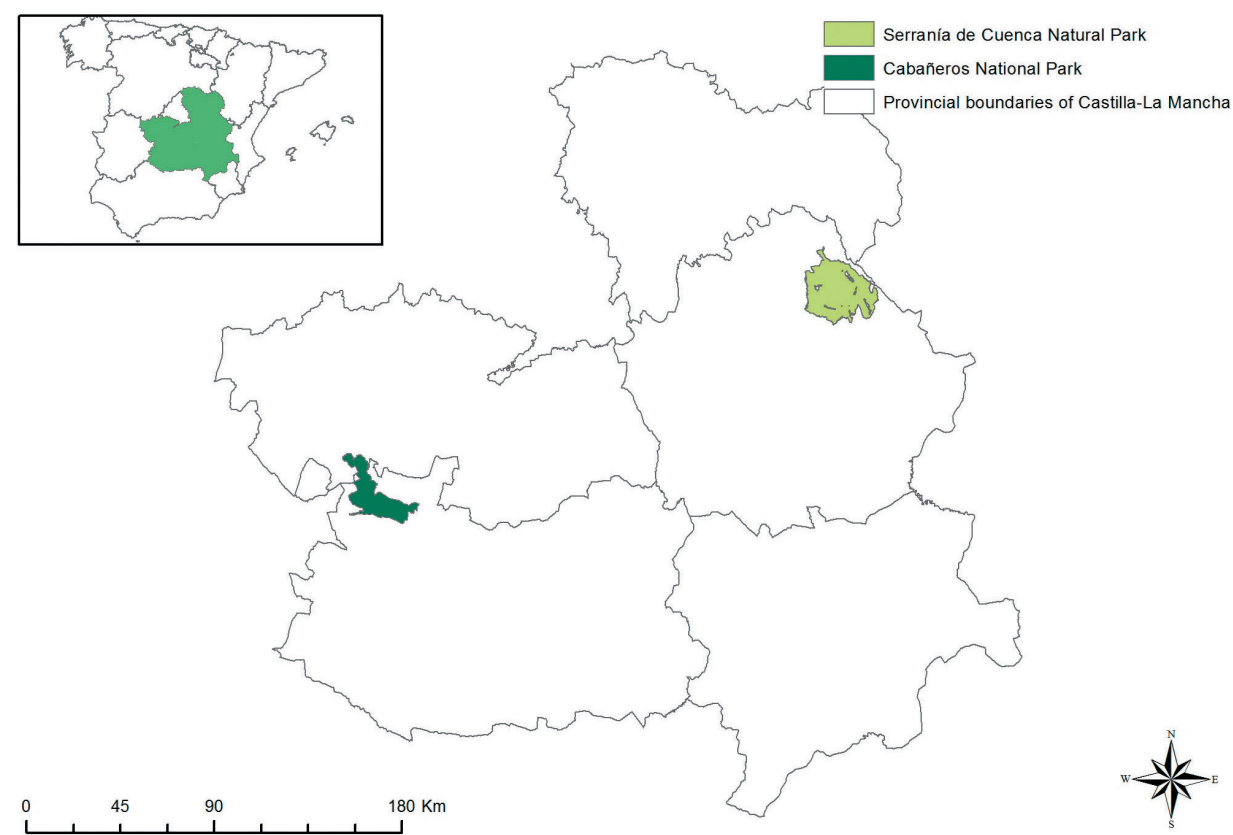

Fig. 1. Location of Cabañeros National Park and Serranía de Cuenca Natural Park in Castilla-La Mancha region -Spain

Table 1. Municipalities and area occupied by Cabañeros National Park in each municipality included within the Area of socio-economic influence

\begin{tabular}{|l|l|c|c|c|c|c|}
\hline \multicolumn{1}{|c|}{ Municipalities } & Province & $\begin{array}{c}\text { Inha- } \\
\text { bitants } \\
\mathbf{2 0 1 3}\end{array}$ & $\begin{array}{c}\text { Surface } \\
\text { (ha) }\end{array}$ & $\begin{array}{c}\text { Area oc- } \\
\text { cupied by } \\
\text { the Park } \\
\text { (ha) }\end{array}$ & $\begin{array}{c}\text { Municipal } \\
\text { protected } \\
\text { area (\%) }\end{array}$ & $\begin{array}{c}\text { \% of the } \\
\text { area of } \\
\text { the Park }\end{array}$ \\
\hline Alcoba de los Montes & Ciudad Real & 659 & 30,710 & 15,520 & 50.5 & 38.0 \\
Horcajo de los Montes & Ciudad Real & 987 & 20,844 & 6,174 & 29.6 & 15.1 \\
Navas de Estena & Ciudad Real & 291 & 14,654 & 9,817 & 67.0 & 24.0 \\
Retuerta del Bullaque & Ciudad Real & 1,063 & 65,391 & 3,743 & 5.7 & 9.2 \\
Hontanar & Toledo & 176 & 15,177 & 2,964 & 19.5 & 7.3 \\
Navalucillos (Los) & Toledo & 2,476 & 35,594 & 2,638 & 7.4 & 6.5 \\
\hline \multicolumn{2}{|l|}{ TOTAL } & 5,652 & 182,370 & 40,856 & 22.4 & 100.0 \\
\hline
\end{tabular}

Source: Spanish Statistical Office, 2014. 
Table 2. Municipalities and area occupied by Serranía de Cuenca Natural Park in each municipality included within the Area of socio-economic influence

\begin{tabular}{|c|c|c|c|c|c|c|}
\hline Municipalities & Province & $\begin{array}{c}\text { Inhabi- } \\
\text { tants } 2013\end{array}$ & $\begin{array}{c}\text { Surface } \\
\text { (ha) }\end{array}$ & $\begin{array}{l}\text { Area occu- } \\
\text { pied by the } \\
\text { Park (ha) }\end{array}$ & $\begin{array}{c}\text { Municipal } \\
\text { protected } \\
\text { area (\%) }\end{array}$ & $\begin{array}{l}\% \text { of the } \\
\text { area of the } \\
\text { Park }\end{array}$ \\
\hline Arcos de la Sierra & Cuenca & 102 & 4,100 & $1,1784.52$ & 43.5 & 2.4 \\
\hline Beamud & Cuenca & 53 & 2,400 & $2,380.62$ & 100.0 & 3.2 \\
\hline Cuenca & Cuenca & 56,107 & 91,100 & $34,278.94$ & 37.6 & 45.3 \\
\hline Huélamo & Cuenca & 116 & 7,900 & $7,902.16$ & 100.0 & 10.4 \\
\hline Majadas (Las) & Cuenca & 294 & 8,700 & $8,730.17$ & 100.0 & 11.5 \\
\hline Portilla & Cuenca & 72 & 3,300 & $1,995.00$ & 60.5 & 2.6 \\
\hline Tragacete & Cuenca & 310 & 6,100 & $6,117.12$ & 100.0 & 8.1 \\
\hline Uña & Cuenca & 98 & 2,300 & $2,332.57$ & 100.0 & 3.1 \\
\hline Valdemeca & Cuenca & 92 & 7,000 & $6,970.64$ & 100.0 & 9.2 \\
\hline Villalba de la Sierra & Cuenca & 529 & 4,100 & $1,847.36$ & 45.1 & 2.4 \\
\hline Zafrilla & Cuenca & 78 & 10,600 & $1,328.23$ & 12.5 & 1.8 \\
\hline \multicolumn{2}{|l|}{ TOTAL } & 57,851 & 147,600 & $75,667.33$ & 51.3 & 100.0 \\
\hline
\end{tabular}

Source: Spanish Statistical Office, 2014.

\section{Hypothesis and objectives}

The initial hypothesis that supports the objectives of the project research framework is that the success of the socio-economic development of natural spaces depends on the existence of social capital, i.e. of the links and interactions between people and institutions at different scales.

This hypothesis is broken down into the following sub-hypotheses and objectives at this stage of the project:

- H1. The strength of the existing local democracy translates into greater agility and transparency of forms of participation and management of the protected natural space.

- 01. To analyse the frequency and content of the meetings of the collegiate bodies of both parks, as well as the perception of the local population about the various environmental tools available to them.

- H2. Situations of social conflict associated with the Declaration and the management of the protected natural space reflect the role played by the population (the state of involvement of local society in these spaces).

- 02 . To read the perception of the members of the collegiate bodies and of the local associations about the generation of conflicts and problems among the local population.

- H3. The trust in collective action depends on the role played by the Administration in terms of responses to individual and collective needs.

- O3. To evaluate programs and investments made in the field of socio-economic development (quantity, continuity and planning) linked directly to its Declaration as a protected natural area. 


\section{Methodology and sources}

The research project uses a combination of social research methods including quantitative and qualitative, direct and indirect sources. Thus, in this phase of the project, with strongly qualitative nature, we have addressed the collection, treatment and analysis of the following:

- Indirect sources: Search and analysis of internal documents of an administrative nature such as the minutes of the meetings of the Board of Trustees (Cabañeros National Park) and Governing Board (Serranía de Cuenca Natural Park) of each Park and the annual reports on their work.

- Direct sources: development of a standardized questionnaire that was distributed among the members of the collegiate bodies of the parks and all associations based in the municipalities of the area of socio-economic influence who agreed to collaborate under the research in spring of 2011. A sample of 55 completed standardized questionnaires ( 25 from the members of collegiate bodies of the parks and 30 from the members of associations) was finally obtained. They were supplemented with four semi-structured in-depth interviews with a sample of key informants (the director-curators of both parks and the managers of the Local action groups operating in both territories) to whom their responsibilities and/or position provide an overview enriched on many occasions with the diachronic analysis capability.

\section{Overview of the Nature Protection System in spain}

Since the inauguration of that first Covadonga National Park in 1918 until today, the protection of nature has grown greatly in Spain. In the intervening ninety five years, one and a half thousand protected spaces have been declared, slowly at first and then almost explosively in recent decades, to reach over 1,600 currently in operation. In total, these represent a little more than six million hectares of land and another quarter million hectares of marine areas. In other words, $12 \%$ of the surface area of Spain is today protected with regard to its natural values. This calculation includes 15 spaces classified under the category of National Park and hundreds of natural parks, nature reserves, monuments and other protection categories that are not always easy to classify due to a large variety of names and specific regulations that have been created as the various administrations at the State, Regional and, in some cases Provincial or Insular levels have developed their powers in this area. The regional legislation contains up to 48 different forms of protection: natural landscape, picturesque landscape, wildlife refuges, peri-urban parks, etc.

The current 155 declared natural parks aim to make conservation and sustainable rural socio-economic development compatible. 290 natural monuments cover places of exceptional geo-morphological and geological value, 265 nature reserves are aimed at conserving singular species and habitats and 53 protected landscapes are intended to preserve traditional cultures essential for the character of a territory.

In Spain, the Central Government is responsible for the basic legislation concerning the protected natural areas. However, the declaration and management of these lies with the Autonomous Communities (Regions). National Parks are declared by the Parliament Act and subject to a common legal framework, i.e. the Law on National Parks Network (Table 3). 
Table 3. Institutional context of the Natural Protected Areas in Spain

\begin{tabular}{|c|c|c|}
\hline & National Parks & $\begin{array}{l}\text { Natural Parks, Nature Reserves, Natural } \\
\text { Monuments and Protected Landscapes }\end{array}$ \\
\hline $\begin{array}{l}\text { Legal } \\
\text { framework }\end{array}$ & $\begin{array}{l}\text { Parliament Act, subject to the common } \\
\text { legal framework, the Law on National Parks } \\
\text { Network. }\end{array}$ & $\begin{array}{l}\text { Up to } 48 \text { different protection categories } \\
\text { derived from } 17 \text { regional legislations. }\end{array}$ \\
\hline $\begin{array}{l}\text { Management } \\
\text { models }\end{array}$ & $\begin{array}{l}\text { Managed by the Autonomous Community } \\
\text { in whose territory they belong. } \\
\text { The management can be direct or through } \\
\text { a governing board: } \\
\text { Board of Trustees of the Park (advisory } \\
\text { body) which supports the Directorate of } \\
\text { the Park (technical and executive body). } \\
\text { Both professionals and administrative staff } \\
\text { of the Park locate in the Management } \\
\text { Office, usually settled within or in the limits } \\
\text { of the National Park. }\end{array}$ & $\begin{array}{l}\text { Managed by the Autonomous Communi- } \\
\text { ties in whose territories they are located, } \\
\text { directly or through autonomous agencies. } \\
\text { Governing board of the Park (advisory } \\
\text { body) which supports the Directorate of } \\
\text { the Park (technical and executive body). }\end{array}$ \\
\hline $\begin{array}{l}\text { Financial } \\
\text { support }\end{array}$ & $\begin{array}{l}\text { Central Government (Royal Decree } \\
940 / 1999 \text { ) exclusively or supplemented } \\
\text { with the regional support. }\end{array}$ & Regional Government \\
\hline $\begin{array}{l}\text { Socio-econo- } \\
\text { mic develop- } \\
\text { ment support }\end{array}$ & $\begin{array}{l}\text { Direct grants for the socio-economic } \\
\text { development of the territory funded by the } \\
\text { central government }\end{array}$ & $\begin{array}{l}\text { Subsidies created by the regional govern- } \\
\text { ments. } \\
\text { Known as the "Green Fund" in Castilla- La } \\
\text { Mancha }\end{array}$ \\
\hline
\end{tabular}

Source: elaborated by the authors.

The Natural Parks, Nature Reserves, Natural Monuments and Protected Landscapes (figures referred by the Law 42/2007) are managed directly by the Autonomous Communities on whose territory they are located, or through the autonomous agencies. National Parks are managed by the Autonomous Community to whose territory they belong. In the case of those which extend within the territories of two or more autonomous communities, the communities must jointly agree a form of integrated management. The management can be direct or through a governing board (Board of Trustees of the Park).

Other institutions managing Protected Natural Areas include the Island Councils of the Canary Islands, the Provincial Councils of the Basque Country, the Balearic Island Councils, and the Provincial Council of Barcelona.

In Spain the Protected Natural areas are funded mainly from the public funds, though even that is not enough to avoid the loss of their biodiversity. Therefore, it is necessary to increase economic resources. This is an important point to consider, especially in the protected areas where the development opportunities are needed to maintain the populations within. On the one hand, money has to be provided by different administrations in order to safeguard preservation and conservation, as well as sustainable development in natural areas. However, the amount of money is really an important obstacle and so is the focus on visitors. On the other hand, many local development groups have obtained grants for local sustainable development initiatives related to tourism. However, in many cases the tourism does not mean that a sustainable development and financing is an unfinished business in many natural areas. There are many things that need to be done, but 
there is very little money for financing them. Local initiatives have been developed within the EU policies, such as ERDF, Leader or Life, with different agents involved. They put the emphasis also on tourism or on the initiatives based on tourism, but include other issues as well. In this context one should also consider agricultural grants, but the importance of agriculture in the natural areas is diminishing.

Whether the protected natural spaces achieve their goals depends on many factors, some of them of internal character regarding the nature conservation administration itself, while other being external factors related to different aspects that influence the territory, resources and ecosystems. The protected natural spaces must enhance their capacity to support the complex systems they contain. The dimensions of management capacity include governability (political support, legislation and government capacity), social support (involvement and support of the local community, owners and other social groups), planning instruments (strategic plans, executive plans) and resources (human, financial, infrastructures and knowledge).

\section{Findings and discussion}

\section{Normative Trust}

The research conducted by Stern (2008a, b) identified two dominating explanatory paradigms in the global conservation community that explained public opposition to parks: the first one, the most important, economic rationalism suggesting that local residents respond primarily to economic stimuli; the second one reflecting themes of democracy and human rights and suggesting that local participation in park management processes is of central importance for defusing park-people conflicts. Furthermore, Stern suggested that local distrust of park managers was the most consistent predictor of active opposition to natural protected areas, which was overshadowing any rational assessments of the benefits and disadvantages associated with the park presence, such as environmental values or local peer attitudes (Stern 2008a, b).

We must remember that our first hypothesis was: the strength of the existing local democracy translates into greater agility and transparency of forms of participation and management of the protected natural space. To verify this hypothesis we have attempted to analyse the frequency and content of the meetings of the collegiate bodies of both parks, as well as the local population perception of the various environmental tools available to them.

In this sense, we attach particular significance not only to the assessment of scepticism of the members of the associations surveyed in terms of their ability to influence the decision-making process of the Park management - something that could cross out subjectivity - but we also take into consideration the way of collegiate bodies functioning, i.e. the frequency and form, seems to come to support theories that point to a certain weakness of the prevailing democratic culture.

In the case of Cabañeros National Park, the participation institution and support for the management of the national park is a Board of Trustees that has been made up of local, State and regional administrations as well as representatives of associations, organizations and institutions whose interests are related to the National Park. It is a consultative and representative body. It is composed of 24 members and meets once a year. The 
representatives of different public administrations (State, regional, local and supra-municipal) make up $53 \%$ of its members.

In the case of Serranía de Cuenca Natural Park there is a Governing Board of the Park composed of 35 representatives: 25 of them are institutional while 10 of them have a socio-economic profile linked with the territory. Since the creation of the Park in the spring of 2007, the Governing Board members have met on 7 occasions, first time in October of the same year it was established in to designate their main offices and to approve the location and contents of the three Interpretation Centres previously proposed by the regional government. Later on, the Governing Board had three meetings in 2009 coinciding with the presentation of the projects for the Interpretation Centres; information on the forest fires which ravaged a part of the Park that summer; and elaboration and approval of the statutes of the Governing Board. Among other things the statutes referred to the establishment of four commissions: Permanent Commission, Local Administration, Conservation Commission and Commission for socio-economic development, the last one having met only once in July 2010. The Governing Board had again a meeting for the fifth time in November 2010 and since that time it has met twice by 2013.

From our analysis of the questionnaires it appears that the concept of reciprocity and solidarity has a pragmatic aspect of common interest that is more tangible and able to be instrumentalized than the generic concept of trust which appears to be given usually for free, except for the previous negative experiences. On the other hand, this is consistent with the social capital theory which considers the trust index to have an opposite trend regarding group size and group closeness. These same contradictions are present in the various theories on the role of social capital in mountain areas; some scholars stress that the mountain regions are still characterised by a system of strong community relationships (Magnani and Struffi 2009) compared to other types of rural areas, while others claim that the mountain communities are often "divided societies" (Osti 2000) where the accelerated change brought by modernisation has flanked long-standing rivalries among families with new conflicts between professional categories (farmers, cattle breeders, tourist entrepreneurs) pursuing different and sometimes contrasting economic goals.

Regarding the information on the environmental tools (Table 4) the assessment and the degree of agreement on the possibilities of participation and management by the local population is much greater in Cabañeros than in Serranía de Cuenca, both among the members of the collegiate bodies and among the associations interviewed. Thus, the average score for the statement "Managers and representatives of the Park take into account the opinion of the local people" among the representatives of Serranía de Cuenca is situated between "strongly disagree" and "disagree". On the other hand, we cannot fail to note that when inquiring about the interest of the population to know something more about the functioning of the protected natural area the answers of the members of the collegiate body are more sceptical than those of the associations contacted; this seems reflecting problems of communication and absence of a real culture of participation in the management of protected natural areas.

The Participatory and Negotiated Territorial Development (PNTD) approach sets out strategic lines of territorial development to overcome the challenges described above. The debate on the danger of including marginalized and disadvantaged actors in a process of negotiation, dialogue, without strengthening their bargaining power and realizing their rights remains open. Also, negotiation processes have to be conducted so that the 
Table 4. Information about environmental tools

\begin{tabular}{|c|c|c|c|c|c|c|c|c|}
\hline \multirow{3}{*}{$\begin{array}{l}\text { Do you think the local population living in/close to the } \\
\text { Park you represent feels identified with the following } \\
\text { statements regarding the management bodies of the } \\
\text { Park? / Do you agree with the following statements } \\
\text { regarding the management bodies of the Parks? }\end{array}$} & \multicolumn{4}{|c|}{$\begin{array}{l}\text { CABAÑEROS } \\
\text { NATIONAL PARK }\end{array}$} & \multicolumn{4}{|c|}{$\begin{array}{l}\text { SERRANÍA DE CUENCA } \\
\text { NATURAL PARK }\end{array}$} \\
\hline & \multicolumn{2}{|c|}{ 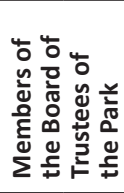 } & \multicolumn{2}{|c|}{ 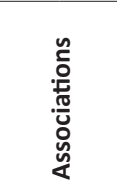 } & \multicolumn{2}{|c|}{ 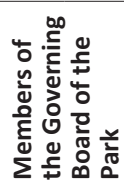 } & \multicolumn{2}{|c|}{ 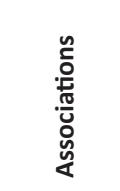 } \\
\hline & $\stackrel{\frac{c}{\sqrt[C]{d}}}{\sum}$ & 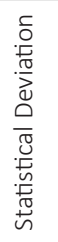 & 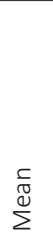 & 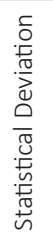 & 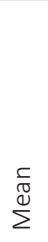 & 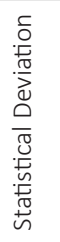 & $\stackrel{\frac{1}{\mathbb{N}}}{\stackrel{\mathbb{N}}{\Sigma}}$ & 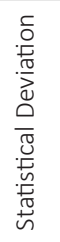 \\
\hline $\begin{array}{l}\text { 1. The information that you are interested in comes to } \\
\text { you clearly in time / The information of the management } \\
\text { bodies of the Park we are interested in comes to us clearly } \\
\text { in time }\end{array}$ & 2.6 & 0.5 & 3.3 & 0.7 & 2.5 & 0.7 & 2.7 & 0.7 \\
\hline $\begin{array}{l}\text { 2. There are opportunities to discuss matters with the } \\
\text { managers of the Park }\end{array}$ & 3.2 & 0.4 & 3.1 & 0.9 & 2.6 & 0.8 & 2.0 & 1.2 \\
\hline $\begin{array}{l}\text { 3. They know to whom and where to go to solve problems } \\
\text { related to the management of Park / I know to whom and } \\
\text { where go to solve Park management problems affecting } \\
\text { me }\end{array}$ & 3.0 & 0.0 & 3.0 & 0.7 & 2.9 & 0.7 & 2.5 & 1.0 \\
\hline $\begin{array}{l}\text { 4. Managers and representatives of the Park take into } \\
\text { account the opinion of the local people }\end{array}$ & 3.0 & 0.0 & 2.9 & 1.2 & 2.3 & 0.9 & 1.8 & 1.0 \\
\hline $\begin{array}{l}\text { 5. There are tools available to the population to consult or } \\
\text { submit claims, if necessary, to the Park managers / There } \\
\text { are tools at my disposal to consult or to submit claims, if } \\
\text { necessary, to the Park managers }\end{array}$ & 2.8 & 0.4 & 3.0 & 0.7 & 2.6 & 0.7 & 2.4 & 0.9 \\
\hline $\begin{array}{l}\text { 6. They feel interested to know more about the Park's } \\
\text { operation / I am interested to know more about the Park's } \\
\text { operation }\end{array}$ & 2.8 & 0.4 & 3.3 & 0.7 & 2.6 & 0.6 & 3.1 & 1.3 \\
\hline
\end{tabular}

Response categories: 1 = strongly disagree; 2 = disagree; 3 = agree; 4= strongly agree.

fundamental human rights (political, socio-economic, cultural, and environmental) of the actors are not questioned (FAO 2005).

As we have already pointed out in the introduction, we should not forget that mere timely and exclusive conservation of some valuable ecosystems, developing minimum activities of management and administration, and with a naturalistic approach excluding and marginalizing sometimes the demands and interests of the affected local people, is today an obsolete approach renewed from the seventies of the last century as a result of the implementation of international proposals, and especially in the last decade of the last century when it passed to a more integrated and globalizing paradigm leaning directly on planning tools (territorial, physical, economic, etc.) and trying to reconcile the claims of conservation with the socio-economic and territorial space environment. The central challenge is to find the ways of putting people back into conservation. Such participation will not be easy as the term itself is interpreted in many different ways. The new vision will need a new professionalism, new supportive policies, and innovative inter-institutional arrangements (Pimbert and Pretty 1995). 
On the other hand, establishment of some protected natural areas can involve, and indeed occasionally has led to, changes not only with respect to the symbolic appropriation of the territory (landscape, etc.) but also of the natural resources by other social actors in the newly protected area. In this way the areas historically shaped as structural elements of local identity and claimed for its own, which have been used for survival and recreation of the local population (grazing, firewood, hunt, mycology, etc.) until the declaration of such natural space, become appropriated by the dominant social classes and/or more educated people raising the gap between visitors and users frequenting such spaces and traditional residents (Picon 1989).

The declaration of a protected natural area involves a series of legal and administrative easements and charges, as well as social, economic and administrative changes that are often considered negative as they directly affect both the local population and the owners of the heritage (communal, municipal, private individuals, etc.), because for good measure the intrusion of the Administration in the social life of the affected population at different scales, especially in its socio-cultural and territorial setting, carry a historic burden in rural communities. All this maze of conflicts can be triggered by public performances against the socio-economic function and development with an implicit presence of the protected natural area.

\section{Territorial Expectations}

The third hypothesis reads that trust in collective action depends on the role played by the Administration in terms of responses to individual and collective needs. For testing purposes we evaluated programs and investments made in the field of socio-economic development (quantity, continuity and planning) linked directly with the Declaration of a protected natural area.

Obviously the territorial expectations are depend on the experience and knowledge of reality available to the stakeholders, resident or not, on the territory affected by each of the two analysed Parks (Table 5). Thus, the fact that until 2006 the administration and management of the National Park have relied on the central administration only from which important subsidies came and still come could explain the ambivalent relationship of the population with the regional administration. Equally, based on their particular national park status, the flagship of protected natural areas network, and the effort made in terms of socio-economic development by the Administration, one can understand the favourable valuation of interviewees in Cabañeros when asked if the Declaration has enabled to strengthen support to the inhabitants of the area and create new opportunities for economic development.

Since the end of the 1980s the central government has been funding a set of measures designed to contribute to the maintenance of national parks by providing socio-economic compensations to the local populations. Since that time subsidies have gone to initiatives with a dual purpose: on the one hand, the strengthening of protected areas and, on the other, offset for the populations of the areas of socio-economic influence (hereinafter ASEI). In any case, up to the annual call for 1998 only the councils located in the ASEI could be beneficiaries of aid. Since 1999 the new rules explicitly provide that public aid or subsidies are intended to promote sustainable development and also the improvement of the quality of life of people living in the ASEI of the parks. But one of the most interesting contributions will be the one relative to the extension of beneficiaries from 
Table 5. Territorial expectations

\begin{tabular}{|c|c|c|c|c|c|c|c|c|}
\hline \multirow{3}{*}{$\begin{array}{l}\text { The declaration of this Protected Natural Space has } \\
\text { allowed: }\end{array}$} & \multicolumn{4}{|c|}{$\begin{array}{l}\text { CABAÑEROS } \\
\text { NATIONAL PARK }\end{array}$} & \multicolumn{4}{|c|}{$\begin{array}{l}\text { SERRANÍA DE CUEN- } \\
\text { CA NATURAL PARK }\end{array}$} \\
\hline & \multicolumn{2}{|c|}{ 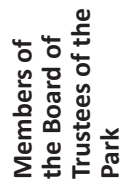 } & \multicolumn{2}{|c|}{ 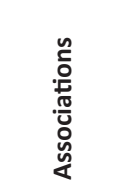 } & \multicolumn{2}{|c|}{ 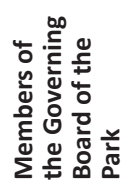 } & \multicolumn{2}{|c|}{ 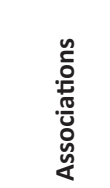 } \\
\hline & 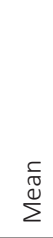 & 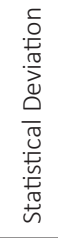 & $\underset{\substack{\tilde{D} \\
\stackrel{\mathbb{U}}{\Sigma}}}{\stackrel{\mathbb{N}}{\Sigma}}$ & 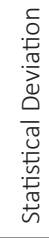 & 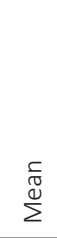 & 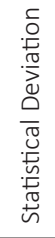 & 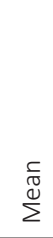 & 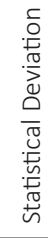 \\
\hline 1. To increase the subsidies to the inhabitants of the area & 2.8 & 0.4 & 3.2 & 0.8 & 2.4 & 1.0 & 1.9 & 1.1 \\
\hline 2. To create new opportunities for economic development & 3.2 & 0.8 & 3.6 & 0.5 & 2.6 & 1.0 & 1.9 & 1.0 \\
\hline 3. To Protect the natural environment & 3.8 & 0.4 & 4.0 & 0.0 & 2.8 & 1.0 & 2.6 & 0.9 \\
\hline 4. To preserve the cultural heritage & 2.8 & 0.4 & 2.2 & 0.4 & 2.3 & 0.8 & 2.6 & 0.9 \\
\hline $\begin{array}{l}\text { 5. To enhance the recreational use of the area and to } \\
\text { attract tourists }\end{array}$ & 3.0 & 1.0 & 3.8 & 0.7 & 2.3 & 0.9 & 2.6 & 0.9 \\
\hline $\begin{array}{l}\text { 6. To generate conflicts and problems in the local } \\
\text { population }\end{array}$ & 1.8 & 0.4 & 1.3 & 0.7 & 2.2 & 0.5 & 1.6 & 0.5 \\
\hline \multicolumn{9}{|l|}{ In general, do you agree with the following statements? } \\
\hline 7. I trust in the operation of the companies in my territory & 2.8 & 0.4 & 3.2 & 0.8 & 2.6 & 0.5 & 2.6 & 0.7 \\
\hline 8. I am confident in the future of my territory & 3.4 & 0.5 & 3.0 & 0.7 & 3.1 & 0.7 & 2.8 & 1.1 \\
\hline
\end{tabular}

Response categories: Questions 1= very little, 2= little, 3= quite; and 4= much. / Questions 1= strongly disagree; 2 = disagree; 3 = agree; and 4= strongly agree.

being exclusively councils in these areas to encompass a wider range. The help may be requested also by local governments and groupings of municipalities of the ASEl; private enterprises whose main activity is developed or run in the ASEI and whose headquarters are located in such a zone; residents and private owners that live in the ASEI; and non-profit institutions which develop actions in the field of conservation of the national parks in the ASEI.

If we take the data provided by the Management Office of the National Park as a reference, in the period 1999-2012 more than EUR 12 million have been invested in socio-economic promotion from the national budgets, of which $63.7 \%$ have been designed for councils of the Park ASEI. It is followed, although at a distance, by the amount earmarked for the companies and self-employed which are the second block of beneficiaries of this type of aid representing 16.9\%; 15.09\% being allocated to individuals, associations and institutions which since 1999 have considerably increased their weight. Finally, the beneficiaries which have received the lowest amount of aid in order to develop their projects and also for some years have not enjoyed such support (1999, 2002 and 2004) have included the associations of municipalities totalling the $4.21 \%$.

In addition to the direct grants for the socio-economic development of the territory, the National Park has made numerous investments in the provision and improvement 
of infrastructure within the Park, which has resulted in its appeal and ability to attract visitors and tourists. The infrastructure includes the visitors' centres Casa Palillos (with botanical and ethnographic path) and Torre de Abraham (botanic-fluvial path) as well as the visitors' centre of Castellar de los Bueyes mountains in Horcajo de los Montes, pending opening.

Furthermore, the ASEI of Serranía de Cuenca Natural Park has benefited from subsidies granted by the regional government of Castilla-La Mancha, known as the "Green Fund", significant but far more limited than the those perceived by the population of the ASEI of national parks. Therefore, the assessment of the increase in support to the inhabitants of the area and the new opportunities of economic development of the region are seen with scepticism, especially among the representatives of the associations interviewed. The complete data series concerning the grants for the socioeconomic development of the ASEI of Serranía de Cuenca covers the calls made from 2007 to 2010, when the last call was made at the end of the year with resolutions adopted at the end of 2011. As evidenced by the data consulted, the annual amount of the subsidies has been declining progressively until a little more than $50 \%$ of the initial values with a distribution between councils, within a limited amount of $€ 30,000$ per municipality, businesses and self-employed (intended for agricultural activities, hotels and tourism), and individuals (with a maximum of $€ 3,000$ ) for conditioning and improvement of housing, including the heating system, all of which raises investment to more than 2.3 million Euros. In terms of direct investments made by Castilla-La Mancha regional government the three visitors' centres built inside the park are the most noteworthy (with a total investment between building cost and exhibition display of $€ 4,110,468.72$ ), although only one of them was opened in the spring of 2010, while the three are finished and waiting to find a viable economic maintenance solution in the current situation of serious economic crisis. In fact, the only one opened, the Uña visitors' centre closed in December 2011 and currently still pending a solution for its reopening.

In terms of environmental protection, virtually all interviewees in the ASEI of Cabañeros National Park agree with the statement that the declaration has allowed improving their chances, while the interviewees of Serranía de Cuenca Natural Park are less enthusiastic about the matter. In this regard, it is worth remembering that while Serranía de Cuenca is an open space without barriers or restrictions on the entry from any access point, where there are privately owned places such as the Ciudad Encantada that draws "real floods" of visitors without record, not to mention seasonal hunters, visitors going to the rutting grounds in the autumn, and, in general, hikers and tourists who frequent the Park, in the case of National Park the space is fenced and access is limited and controlled by the visitors management system. In the evolution of visits to the latter a significant increase is perceived from the moment when it is declared National Park (1995), a date on which the number of 15,000 visitors was exceeded and which was a starting point for a sustained visitors increase over the years. In 1998, the Park had more than 50,000 visitors a year and in the year 2012 this number already exceeded 81,000 annual visits. This suggests that gradually the widespread trend of Cabañeros visits has been growing despite the limitations and restrictions that the Park suffers when it comes to channel flows (it is a National Park with a lower rate of visitors/hectare per year of the entire Spanish network), one of the main reasons of the conflict between the Directorate of the Park and the agents invoIved in rural tourism in the area (accommodation, tourism entrepreneurs, etc.). 
Moreover, conservation of the cultural heritage stimulates similar responses among interviewees in Cabañeros and Serranía de Cuenca who are of the opinion that the declaration of the space has allowed to improve conservation between little and quite. This response is probably due to the scarcity of the Assets of National Interest or monuments of some notoriety as well as a lack of appreciation of intangible goods or the landscape as a cultural heritage. It is an endless source of surprise that in the case of Serranía de Cuenca that is a space traditionally much more frequented by hikers and tourists than Cabañeros, and has a tourist infrastructure, including both accommodation and vacancies, much more developed than the ASEI of the National Park, the assessment of the effect that the declaration has had on the increase of the tourist/recreational use of the area is much more positive in Cabañeros than in Serranía de Cuenca. Certainly, the recent tourist development of the National Park, adapted to the new demands of rural tourism compared to the infrastructure of the Natural Park that has become partly obsolete, explains this paradoxical situation.

Recently, by end of 2009, the Cabañeros National Park has signed the European Charter for Sustainable Tourism in Protected Areas, an initiative which aims to move forward effectively based on the principles of sustainable tourism in protected natural areas, granting accreditation to those who have made a commitment to meet this objective. The European Charter for Sustainable Tourism was developed between 1995 and 1998 by the professionals and managers of the Park and representatives of the tourism industry and is funded under the LIFE programme of the European Union.

Last but not least, our second hypothesis reads that situations of social conflict associated with the Declaration, and to the management of the protected natural space reflect the role played by the population (the state of involvement of local society in these spaces). In order to verify this idea we have attempted to find the perception of the members of the collegiate bodies and of the local associations about the generation of conflicts and problems among the local population.

To complete this set of questions, when interviewees were asked about the impact of the declaration in the emergence of conflicts with local population, the first thing that should be noted is that the answers obtained as a whole indicate "very little" or "little" and only in the case of the members of the Governing Board of the Natural Park scores placed its value between "little" and "quite". The perception of the territory, as well as its management by the agents involved therein, can crystallize in very different ways (conflicts, struggles, co-operation, cohesion, etc.). In that sense, the analysis of the set of allegations to the draft of the Master Plan for the Use and Management (hereinafter MPUM) of Cabañeros can be considered an indicator of the different interpretations of space linked with the National Park, collecting different points of view from stakeholders that interact in the territory.

The analysis of themes or causes of allegations presented gives us a classification including two major thematic blocks. On the one hand, the restrictions associated with the traditional uses permitted or not following the future adoption of the MPUM, which scored 26 claims in total, and on the other, those related to infrastructure, equipment and facilities, generating other 25 reports, and that added up to 14 filed due to problems of access to the Park accumulate 39 allegations. As for the remaining categories, they have been classified as the claims, except those relating to coordination between agents (Directorate of the Park, owners, local population, etc.) with a single report, accumulated 
between 6 and 16 reports. Tourism within the ASEI of the Park is one of the recurrent themes of many allegations, in particular 16, many of them filed by mayors of the affected municipalities which saw limited expectations.

As expected, the coincidence between the various stakeholders in the four sections is limited. In the case of public use, the Directorate of the Park is in favour of visits controlled by signposted routes, including visits in off-road vehicles; at the same time, it aims to alleviate the tourist seasonal standstill as the visitors are concentrated mainly in spring and autumn (the rutting season) while summer and winter numbers of visitors flows descend significantly. Instead, the councils seek to establish more routes in the Park and put ever growing expectations for the region on tourism which directly support the tourist entrepreneurs who wish to increase the number of visitors to the Park (Caro et al. 2009).

Regarding to development initiatives positions are equally diverse. In the opinion of the Directorate of the Park they should support the initiatives of rural houses, assuming a switch of the regional economy towards the services as a complement to farm income through the financial support from the rural tourism revenue in the area. On the other hand, the association of local people concerned (Aprofinca) defends its point of view expecting a greater control of aid and asserting that there are few aids to the owners and farms. However, all actors believe that it is a fundamental support for the social and economic development of the region.

The opinions are also diversified, if we look at the opinion around the line of subsidies granted by the park. For the Park itself they are considered fundamental in guiding the economy of the area, on the other hand, local authorities and tourism entrepreneurs say they ignore the criteria used by the Park Office for granting them, and similarly Aprofinca argues the subsidies are targeted at the local governments which hinder access to them.

Finally, as for to the conservation issue - one of the fundamental pillars of the declaration of any protected area - the Park professionals defend clearly their stance that points towards the conservation of species of flora and fauna as well as the need for research on them and, where there have been alterations of the ecosystem, they are committed to environmental restoration. Now, this pure conservationist stance is not shared by the municipalities which consider the restrictions to be excessive and refer to the management as overly bureaucratic even in conservation. The municipalities are committed to management models including consensus and participation into policy-making concerning the Park. In this sense, Aprofinca argues the suitability of financial compensation to landowners who depleted their activities as a result of the limitations of use on the farms.

In any case, the ongoing disagreements on the use and management of the National Park have resulted in that the Natural Resource Management Plan has been annulled by the Constitutional Court while the Master Plan for the Use and Management has not been still approved after a decade of processing.

In the case of Serranía de Cuenca, where the conflicts have been apparently less acute (there was no significant problems for the declaration of the protected area or the approval of the Natural Resource Management Plan), however, these are perceived more intensely by the members of the Governing Board, perhaps because of a greater susceptibility to the pitfalls and/or clashes of interests that are arising, perhaps because its short life that has not yet favoured the emergence of a culture of effective conflict management. The truth is that conflicts of use have broken out between different stakeholders. The ecological status of the river Júcar has been of concern during dry years. Due 
to the rain shortage and a reduced flow released into the river from La Toba dam it has experienced a critical situation of flow almost drying up a stretch of the river. The section of the river (around $20 \mathrm{~km}$ ) in question is subjected to an alteration of its flow regime by the hydroelectric development in favour of the company Gas Natural-Unión Fenosa. This situation led to a series of meetings both with the concessionaire (Gas Natural-Unión Fenosa) and the Júcar public Water Authority resulting in a number of commitments that would maintain good ecological conditions in the stretch between La Toba dam and Villalba waterfall.

Another area of concern is the conflict between the preservation of birds and sport-recreational activities in different areas of the Park. The pressure of active tourism options on some places is excessive. Therefore information campaigns, renewal of signalling and discussions between the sport enterprises and the Park professionals started. We cannot forget the clashes between traditional farming and certain forms of active tourism (including the emergence of trial motorcycles and quads) that cause conflicts and damages coupled with the problems of erosion and pollution. All of which should lead to the necessary regulation and control of this type of use with priority for traditional grazing.

Though this is not an exhaustive list, we should also remember the different perceptions and expectations of the local population and Park professionals that manifest themselves when, for example, the need for a joint study on treatment of waste water and methods of purification of the municipalities of the area are referred to, thus, although the mayors in the Governing Board do not refuse to deal with them they understand that the priorities of the territory are of the socio-economic nature in order to fix population and promote alternative development, tackling the problem of depopulation that is now threatening the Park.

After analyzing the different aspects and answers about the territorial expectations of both protected areas it is not surprising that those interviewed in Cabañeros show greater confidence in the operation of the companies in its territory as well as in the future of the same. The experience gained in managing conflicts by different Park professionals, as well as the support of the Administration in the form of subsidies and direct investments justify that, despite being a deprived rural territory, plagued by problems of depopulation and ageing, its inhabitants have a more favourable perception of the functioning of the collegiate body and they have expectations opened up by recent developments in rural tourism.

\section{Concluding remarks}

Conflicts between conservation objectives and neighbouring local populations have constantly accompanied the nature protected areas throughout Europe. The two case studies in our research reveal that a complex mixture of factors conceptualised in an explanatory framework shows the general attitude towards the protected areas. The components showing the strongest correlations with the general attitude are (lack of) participation, economic benefits, environmental attitudes and communication (Ruschkowski and Mayer 2011).

First of all, we would mention that "trust" can only be understood in its socio-cultural and territorial context and mutual expectations are the "social glue" that binds most of small rural communities. In this respect, and in relation to the socioeconomic development, 
reciprocity, solidarity and "territorial trust" or trust in the future of the county appear to emerge as much more sensitive indicators than generalized, personal or institutional trust.

Furthermore, the results of the implementation of socio-economic development programmes yield very different outcomes; the reasons could be the amount of subsidies, the degree of efficiency of Park professionals and technical teams of the Local Action Groups, the excessive length of some of the selected territories, located in mountain and disjointed regions, and especially the need for converging on the same territorial problem/problems construction by a number of people and/or entities with alternative identities and alliances in relation to the problem at stake; in this framework the network of alliances and the consensus on which it is based is always precarious and context dependent.

The Differences between the territories as far as development is concerned can be better understood as the result of historical processes in which there has been a certain combination of social and institutional relations. The existence of a rich social capital is not the only "prerequisite" for the development but would have the dual ability to be a resource that could mobilize other resources (economic, political, and cultural capital) in order to generate or expand the economic, cultural, political and social "benefits" always in dialectical relationship.

In any case, bearing it all in mind, we cannot forget that participation tools and culture need to be improved. Meetings of the collegial bodies are scarce and in most cases only serve to approve actions and projects already carried out by the Directorate of the Park, all of which explains the suspicion of the municipal representatives of the territories included within the ASEI as well as of the socio-economic stakeholders. To all of this we must add the fact that subjects and concerns on the agenda of each stakeholder rarely match exactly and the local population has the impression that their interests and opinions are postponed for the benefit of the objectives of Park conservation and its potential tourist function. What is needed this is rethinking of conservation science and practice itself. This will need to draw on emerging experience of post-positivist science and philosophy from other fields as well as ecology itself (Pimbert and Pretty 1995). This new vision for conservation implies new roles for project staff and local people in the protected area management. This calls for a greater emphasis on training in communication rather than technical skills. Outside professionals must learn to work closely with colleagues from different disciplines or sectors as well as with the rural people. The challenges of adapting the ingredients of participatory community based successes to the design and management of national parks and other protected areas are therefore enormous. But it would be socially irresponsible not to pursue actively this approach in the contexts where rural people directly depend on biological diversity and natural resources. According to West et al. (2006) we also would like to see more work specifically focused on what we see as a simplification process that takes place when biologists and other natural scientists write about, think about, and attempt to legislate on the social relations between people and their surroundings (Stern 2006). In this simplification process, rich and full of nuances social interactions connected to what natural scientists see as the environment are condensed to a few easily conveyable and representable issues or topics.

Coming back to our case studies, Cabañeros was declared first a Natural Park and then the National Park in 1995, definitely leading to a social opening of the territory. Previously a debate had erupted about its possible militarization but the citizen opposition managed to turn it as a natural space of established reputation, highlighting the natural 
and landscape values which preserves the ecosystem. Thus, the Declaration has certainly yielded positive consequences, but also negative ones. Among the former, the "social discovery" of this region in the 1980s after it broke in the media as a possible NATO operations Centre. Moreover the territory benefits from European funds which are promoting a progressive economic shift towards a certain tertiary sector with the activities related to the environment and tourism (rural, green, etc.) dominating. This all supposed, along with grants from the National Park Autonomous Agency, a significant improvement in the quality of life of the local population (improvements in housing, infrastructure, roads, services, etc.). That said, the declaration has failed to stop the demographic reduction that show all municipalities of Cabañeros ASEI, which have been losing population steadily with the consequent ageing and the lack of generational turnover due to low birth rates - a process concerning the structural situation in which are involved aspects such as lack of specialized health services and above all the lack of labour expectations for young people. Likewise, actors interested in tourism (municipalities, entrepreneurs, etc.) are still concerned about the problems of public use management and traditional use in the area, as well as they continue striving to increase the number of visitors to the Park.

Moreover, the territory of Serranía de Cuenca Natural Park has poor experience as protected area, a little more than six years, and an exclusive reliance on funds and regional policies, much less generous than those intended for the National Park. Its recent declaration could be the reason for which, despite the absence of noticeable conflicts in its origin, the dissatisfaction expressed by the associations surveyed with the work of the collegiate body and the reservations of the Governing Board about the interest and commitment of local people respond to failures in the participation and management procedures of the Park, still not yet tested and with a clear shortage of professionals (in addition to the Director, the Park Office only has a technician and an administrator), which would explain the gap between the initial expectations of local population and the reality and impact on the socio-economic development of the territory.

On the basis of the foregoing we also support the conclusions of some of the European researches mentioned above, in the sense that confidence in collective action depends on the role played by public administration in terms of responses to individual and collective needs. In other words, the lack of public services results in a community that does not rely on collective action; and, consequently, the will to build social capital appears as very weak. Consequently, when a community is poor in social capital, the public administration must provide a better level of public infrastructure/facilities/services in order to create an atmosphere of trust in the collective action.

\section{Acknowledgments}

The article was prepared as a part of the research Project "Análisis Territorial del Capital Social en Espacios Naturales Protegidos: Indicadores de desarrollo socioeconómico" (CSO2008-02919) funded by the Spanish Ministry of Science and Innovation.

The authors jointly wish to thank the editors of the Rural Studies / Studia Obszarów Wiejskich and the two anonymous reviewers for their inspiring and detailed constructive comments on an earlier draft of this paper. 


\section{References}

Árnason A., Shucksmith M., Vergunst J. (eds.), 2009, Comparing Rural Development. Continuity and Change in the Countryside of Western Europe, Perspectives on rural policy and planning Series, United Kingdom, Ashgate.

Bryden J. M.,1998, Development strategies for remote rural regions: What do we know so far?, paper presented to the OECD International Conference on Remote Rural Areas: Developing through Natural and Cultural Assets, Albarracín, Spain, 5-6 November 1998.

Caro J., Díaz S., Sunyer Lachiondo C., Viñuela J., 2009, Contribución del Parque Nacional de Cabañeros al Desarrollo Rural del entorno, [in:] Sunyer Lachiondo C. (ed.), Eco-emprendedores: Retos para la puesta en valor de los espacios protegidos, TERRA centro para la política ambiental, Madrid, pp. 23-30.

Copus A., Spikeman K., 2003, The AsPIRE Conceptual Framework, Final Report of AsPIRE Project, pp. 13-49 (unpublished).

Florido Trujillo G., Lozano Valencia P. J., 2005, Las figuras de protección de los espacios naturales en las comunidades autónomas españolas: una puesta al día, Boletín de la Asociación de Geógrafos Españoles, 40, pp. 57-81.

Garayo Urruela J. M., 2001, Los espacios naturales protegidos: entre la conservación y el desarrollo, Lurralde, 24, pp. 271-293.

Gomez-Pompa A., Kaus A., 1992, Taming the Wilderness Myth, Bioscience, 42 (4), pp. 271-279.

FAO, 2005, Participatory and Negotiated Territorial Development (PNTD), Natural Resources Management and Environment Department.

Harvey D., 1989, The Condition of Postmodernity: An Enquiry Into the Origins of Cultural Change, Cambridge, United Kingdom, Blackwell.

Katz C., 1998, Whose nature, whose culture? Private productions of space and the preservation of nature, [in:] Braun B., Castree N. (eds.), Remaking Reality: Nature at the End of the Millenium, London, Routledge, pp. 46-63.

Lee J., Árnason A., Nightingale A., Schucksmith M., 2005, Networking: Social Capital and Identities in European Rural Development, Sociologia Ruralis, 45 (4), pp. 269-283.

Magnani N., Struffi L., 2009, Translation sociology and social capital in rural development initiatives. A case study from the Italian Alps, Journal of Rural Studies, 25, pp. 231-238.

Martínez Vega J., Calcerrada R., 2003, Repercusión de los espacios naturales protegidos en la economía rural española, Serie Geográfica, 11, pp. 41-60.

McCleave J., Espiner S., Booth K., 2006, The New Zealand people-park relationship: An explanatory model, Society and Natural Resources, 19 (6), pp. 547-561.

Mulero Mendigorri A., 2002, La protección de espacios naturales en España: antecedentes, contrastes territoriales, conflictos y perspectivas, Madrid, Mundi-Prensa.

Nahapiet J., Ghoshal S., 1998, Social capital, intellectual capital and organizational advantage, Academy of Management Review, 23 (2), pp. 242-266.

Osti G., 2000, LEADER and partnerships: the case of Italy, Sociologia Ruralis, 40 (2), pp. 172-180.

Picon B., 1989, Les espaces naturels sont-ils des supports de differentiation sociale?, [in:] Fourneau F. (ed.), Supervivencia de los espacios naturales, MAPA-Casa de Velázquez, Madrid, pp. 109-117.

Pimbert M. P., Pretty J., 1995, Parks, People and Professionals: Putting 'Participation' into Protected Area Management, United Nations Research Institute for Social Development, International Institute for Environment and Development, World Wide Fund for Nature, Discussion Paper, 57, Geneva. 
Pretty J. N., 1994, Alternative Systems of Inquiry for Sustainable Agriculture, IDS Bulletin, 25 (2), IDS, University of Sussex, pp. 37-48.

Pretty J., Smith D., 2004, Social Capital in Biodiversity Conservation and Management, Conservation Biology, 18 (3), pp. 631-638.

Ruschkowski E. Von, Mayer M., 2011, From Conflict to Partnership? Interactions between Protected Areas, Local Communities and Operators of Tourism Enterprises in Two German National Park Regions, Journal of Tourism and Leisure Studies, 17 (2), pp. 147-181.

Selby, A., Petäjistö, L., 2009, Uneven entrepreneurial responses to demands for tourism-related services adjacent to three national parks in southern Finland (Working papers of the Finnish forest research institute 127), Vantaa, Retrieved December 19, 2009, from http://www.metla. fi/julkaisut/workingpapers/2009/mwp127.htm

Shortall S., 2008, Are rural development programmes socially inclusive? Social inclusion, civic engagement, participation, and social capital: Exploring the differences, Journal of Rural Studies, 24, pp. 450-457.

Smith N., 1990, Uneven Development: Nature, Capital and the Production of Space, Oxford, United Kingdom, Basil Blackwell.

Smith N., 1996, The production of nature, [in:] Robertson G., Marsh M., Tickneret L., Bird J., Curtis B., Putnam T. (eds.), Future/Natural: Nature, Science, Culture, Routledge, London, pp. 35-54.

Stern M. J., 2006, Understanding local reactions to national parks: the nature and consequences of local interpretations of park policies, management, and outreach, PhD thesis, Yale University, New Haven.

Stern M. J., 2008a, The power of Trust: Toward a Theory of Local Opposition to Neighboring Protected Areas, Society \& Natural Resources, 21 (10), pp. 859-875.

Stern M. J., 2008b, Coercion, voluntary compliance and protest: The role of trust and legitimacy in combating local opposition to protected areas, Environmental Conservation, 35 (3), pp. 200-210.

Stoll-Kleemann S., Job H., 2008, The relevance of effective protected areas for biodiversity conservation: An introduction, GAIA, 17 (S1), pp. 86-90.

Tsai W., Ghoshal S., 1998, Social capital and value creation: The role of intrafirm networks, Academy of Management Review, 41 (4), pp. 464-476.

West P., Igoe J., Brockington D., 2006, Parks and Peoples: The Social Impact of Protected Areas, Annual Review of Anthropology, 35, pp. 251-277. 